\title{
High-Carbon Fly-Ash as a Binder for Iron Ore Pellets
}

\author{
FINAL TECHNICAL REPORT
}

September 30, 1997, through September, 29, 1999

\author{
Principal Author: \\ S. K. Kawatra, Department of Metallurgical and \\ Materials Engineering, Michigan Technological \\ University \\ Other Authors: $\quad$ T. C. Eisele, Department of Metallurgical and \\ Materials Engineering, Michigan Technological \\ University \\ S. J. Ripke, Graduate Student, Department of \\ Metallurgical and Materials Engineering, \\ Michigan Technological University \\ G. Ramirez, Undergraduate Student, \\ Department of Chemical Engineering, \\ Michigan Technological University \\ Report Issue Date: \\ September 1999 \\ DOE Award Number: \\ DE-FG26-97FT97271--01 \\ Institutional Address: \\ Department of Metallurgical \\ \& Materials Engineering \\ Michigan Technological University \\ 1400 Townsend Drive \\ Houghton, MI 49931-1295 \\ Project Manager: \\ Robert A. Patton \\ Submitted To: \\ U.S. Department of Energy \\ Federal Energy Technology Center \\ ATTN: Contractor Reports Receipt \\ Coordinator, M/S F07 \\ 3610 Collins Ferry Road \\ P.O. Box 880 \\ Morgantown, WV 26507-0880
}

Patent Information: There is no patentable subject matter disclosed in this report. 


\section{Disclaimer:}

This report was prepared as an account of work sponsored by an agency of the United States Government. Neither the United States Government nor any agency thereof, nor any of their employees, makes any warranty, expressed or implied, or assumes any legal liability or responsibility for the accuracy, completeness, or usefulness of any information, apparatus, product, or process disclosed, or represents that its use would not infringe privately owned rights. Reference herein to any specific commercial product, process, or service by trade name, trademark, manufacturer, or otherwise does not necessarily constitute or imply its endorsement, recommendation, or favoring by the United States Government or any agency thereof. The views and opinions of authors expressed herein do not necessarily state of reflect those of the United States Government or any agency thereof. 


\title{
High-Carbon Fly-Ash as a Binder for Iron Ore Pellets
}

\begin{abstract}
If high-carbon fly-ashes are to be used, applications that are unaffected or improved by carbon content need to be identified. Currently, there are no applications for high carbon fly-ashes. One promising application is as a binder for iron ore pellets used, as blast furnace feed, to produce iron and steel. The objective of this project was to investigate the use of high-carbon fly-ashes as iron ore pellet binders. This is the first attempt to reuse high carbon fly-ash. Iron ore pelletization is a high volume application; during 1998 iron ore pelletization consumed 756,000 metric tons of the current binder, bentonite clay, which is similar in chemical composition to fly-ashes. The cost of bentonite is high because it must be shipped several hundred miles from the Western United States to Minnesota and Michigan's Upper Peninsula, while fly-ash has the benefit of being produced by power plants located within a few miles of iron ore pelletizing plants.

A series of experiments were performed, using a binder consisting of fly-ash with calcium hydroxide as an activator, to determine the effect of three hardening accelerators. X-ray diffraction was used to characterize the reacted and unreacted binder components. Small dosages of calcium acetate, calcium nitrate, and calcium chloride accelerated the binding reaction and produced pellets of industrially acceptable strengths. Iron ore pellets were first made with fly-ash alone as binder, with a binder concentration of $1.5 \%$ by weight of the magnetite concentrate. However, the pellets had insufficient strength. Calcium hydroxide was then added along with the fly-ash at a concentration of $1.0 \%$ by weight of the magnetite concentrate, as an activator. These pellets met the minimum industrially acceptable strength values, since calcium hydroxide improved the wet knock, wet compressive strength, dry compressive strength, and sintered compressive strength of the pellets. Calcium acetate, calcium nitrate, or calcium chloride, at dosages of $0.2 \%$ of the magnetite concentrate weight, accelerated the hardening reaction and improved the dry pellet compressive strengths further, to well above the minimum industrially acceptable values.
\end{abstract}

Fly-ash addition was then decreased to $0.66 \%$, with activator and accelerator dosages constant at $1.0 \%$ and $0.2 \%$, respectively. While the pellet strengths decreased, they still exceeded the minimum industrially acceptable strength values. Fly-ash addition was then eliminated. The resulting pellet strengths decreased dramatically, showing that the fly-ash played a significant role in the binder. Addition of fly-ash to the binder was shown to be as important as accelerator addition. During this project, high carbon fly-ash based binders were used to successfully produce iron ore pellets that exceed the industrially acceptable values for strength, and the pellet quality was independent of fly-ash carbon content in the range of $1.84 \%$ to $6.87 \%$ carbon. 


\section{Table of Contents}

Disclaimer

$\begin{array}{lr}\text { Abstract } & \\ \text { Executive Summary } & 1 \\ \text { Introduction } & 3 \\ \text { Theoretical Discussion } & 4 \\ \text { Experimental Procedures } & 5 \\ \text { Results and Discussion } & 9 \\ \text { Conclusions } & 17 \\ \text { References } & 18\end{array}$

List of Tables

Table 1. Chemical analyses of fly-ashes and bentonites. 5

Table 2. $\quad$ Pellet quality test descriptions. 8

Table 3. $\quad$ Indurated compressive pellet strengths. 15

List of Figures

Figure 1. Schematic of laboratory-scale pelletizing drum. 6

Figure 2. $\quad$ Particle size analyses of magnetite and fly-ashes. 9

Figure 3. X-ray diffraction (XRD) results of as received Unit 2 fly-ash. $\quad 10$

Figure 4. XRD results of unreacted Unit 2 fly-ash based binder (FBB). 10

Figure 5. XRD results of reacted Unit 2 FBB. 11

Figure 6. $\quad$ XRD results of dried FBB bonded pellet. 11

$\begin{array}{lll}\text { Figure 7. XRD results of dried bentonite bonded pellet. } & 12\end{array}$

$\begin{array}{lll}\text { Figure 8. } & \text { XRD results of sintered bentonite bonded pellet. }\end{array}$

Figure 9. Pellet wet knock values - $1.5 \%$ fly-ash addition. 13

Figure 10. Pellet wet compressive strengths - $1.5 \%$ fly-ash addition. 14

Figure 11. Pellet dry compressive strengths - 1.5\% fly-ash addition. 15

Figure 12. Pellet dry compressive strengths - $0.66 \%$ fly-ash addition. 16

Figure 13. Pellet dry compressive strengths - no fly-ash addition. $\quad 17$ 


\section{EXECUTIVE SUMMARY}

Fly-ash utilization has been a popular pollution reduction topic. Previously, researchers have concentrated on uses for the marketable, low-carbon fly-ashes, which make up only a small percentage of fly-ashes currently produced. Some researchers have investigated methods to beneficiate high-carbon fly-ash into a marketable product. However, current significant applications for fly-ash depend on its low cost, and cannot economically absorb the cost of the fly-ash beneficiation. The result is that the majority of the fly-ash produced every year is not being used; nearly $80 \%$ of the fly-ash produced is still landfilled.

A new and significant market for fly-ash is as a binder for iron-ore concentrate pellets. The U. S. Geological Survey estimated that 62 million metric tons of iron-ore pellets were produced in the U.S. in 1998, consuming 756,000 metric tons of bentonite binder, resulting in a potentially significant market for fly-ashes. Iron-ore pellets are only one potential application for such binders. Metal foundries also require binders for their molding sands, and U. S. foundries consume 869,000 metric tons of bentonite per year ${ }^{1}$. These applications are expected to be less sensitive to unburned carbon content than existing applications, and are also likely to allow for processing of the fly-ash before use.

\section{Objectives}

The goal of this project was to convert currently unusable fly-ashes into a material that can be used as a binder for iron ore. Such a binder would also be useful for other high-volume markets, including foundry sand mold binders. Previously, the investigators used fly-ash in combination with calcium hydroxide as an additive while calcium chloride was added as a hardening accelerator. However, the addition of chloride salts have a detrimental effect because chlorine causes corrosion in processing equipment. Therefore, other potential hardening accelerators were investigated during this project.

During production, dried iron-ore pellets are required to have crushing strength of at least 22.2 newtons ( 5 pounds force) per $12.7 \mathrm{~mm}(1 / 2 \mathrm{inch})$ diameter pellet. The pellets are then sintered at temperatures up to $1300^{\circ} \mathrm{C}$ and must not exhibit a significant degree of spalling or cracking. Pellets will therefore be tested to determine whether acceptable dry crushing strengths can be achieved.

\section{Fly-Ashes Being Studied}

For this project, a diverse range of marketable and unmarketable fly-ashes were investigated. Fly-ashes were collected from the E. D. Edwards plant, operated by the Central Illinois Light Company, and were used in their raw state for the binder studies. These ashes were from three separate coal-fired burners, designated Unit 1, Unit 2, and Unit 3. Unit 2 ash is currently unmarketable due to high carbon content, as indicated by its high Loss-On-Ignition (LOI) value. These ashes were:

- Fly-ash from Unit 1, burned 100\% Illinois coal, 1.8\% LOI.

- Fly-ash from Unit 2, burned 75\% Exxon - 25\% Kentucky coal, 6.8\% LOI.

- Fly-ash from Unit 3, burned 60\% Illinois - 40\% Exxon coal, 4.4\% LOI. 


\section{$\underline{\text { Project Results }}$}

The majority of the iron and steel produced in the U. S. comes from iron ore pellets. The inherently fine dissemination of U. S. iron ore bodies results in the production of fine concentrates that must be pelletized to allow for shipping and blast furnace reduction. Iron ore pellets are required by industry to have dry compressive strengths above 22.2 newtons (5.0 pounds-force). The goal of this project was to make industrial strength iron ore pellets with a high-carbon fly-ash based binder. This was the first successful attempt to reuse high-carbon fly-ashes. This goal was achieved, and now allows iron ore pellet producers the option to replace their current bentonite clay binder, and further improve their environmental stewardship, by reusing the otherwise landfilled fly-ash. During this project, pellets made with fly-ash based binders achieved compressive strengths as high as 40 newtons (9.0 pounds-force). This successful project has shown that fly-ash based binders can be used to produce industrial strength iron ore pellets.

Iron ore pellets were initially made with fly-ash alone as binder, with a concentration of $1.5 \%$ by weight of magnetite concentrate. Since these pellets had insufficient dry compressive strength of less than 10 newtons, calcium hydroxide was then added to the binder at a concentration of $1.0 \%$ by weight of the magnetite concentrate, as an activator. These pellets met the minimum industrially acceptable dry strength values of about 22 newtons, since calcium hydroxide improved the wet knock, wet compressive strength, dry compressive strength, and sintered compressive strength of the pellets, of which the dry compressive strength the most important criterion for judging the quality of a pellet binder. Subsequently, accelerators were used at $0.2 \%$ addition; calcium acetate, calcium nitrate, or calcium chloride accelerated the hardening reaction and improved the pellet dry compressive strengths further, to as high as 40 newtons, which is well above the minimum industrially acceptable value of 22.2 newtons.

The fly-ash based binder components were characterized by x-ray diffraction. Reacted and unreacted binders were used to determine the initial and final components of the binders. XRD data support the hypothesis that pozzolanic fly-ash reacted with calcium hydroxide and accelerator to produce an amorphous calcium silicate hydrate gel that acted as binder.

Then, activator and accelerator additions remained constant while the fly-ash addition was decreased to $0.66 \%$ and, while the pellet strengths decreased, they still exceeded the minimum industrially acceptable values. Fly-ash addition was then eliminated and the resulting pellet strengths decreased dramatically. Addition of fly-ash to the binder was therefore shown to be as important as accelerator addition. High carbon fly-ash based binders can be used for iron ore pellets; the pellet strength was independent of fly-ash carbon content in the range of $1.84 \%$ to $6.87 \%$.

Sintered iron ore pellets were made with $1.5 \%$ high carbon fly-ash, with $1.0 \%$ activator and using $0.2 \%$ of either calcium acetate or calcium chloride as accelerator; these pellets sintered to a higher final strength than bentonite-bonded pellets. X-ray diffraction showed that the magnetite in the dry pellets oxidized during sintering and transformed into hematite. Sintered iron ore pellets made with $0.66 \%$ high carbon fly-ash pellets had slightly weaker fired compressive strengths than the bentonite pellets, but still exceed industrial standards. 


\section{INTRODUCTION}

Fly-ash is composed of fine particles of ash, produced during solid fuel combustion, that are carried by waste gasses out through a furnace flue. After the ash is removed by electrostatic precipitation, filtering or a similar process, it must be dealt with. Coal-fired power plants produced nearly 60 million metric tons of fly-ash during $1996^{1}$. The cost to landfill fly-ash is increasing. Coal-fired electrical utilities recognize it is economically and environmentally important to identify ways to utilize fly-ashes in order to reduce the amount that is landfilled.

Over $80 \%$ of the coal fly-ashes produced in the U. S. are unusable because they have a high carbon content. Previous researchers have concentrated on utilizing the $20 \%$ of the fly-ash that is low in carbon, while the high-carbon fly-ashes must still be landfilled as waste. Therefore, new markets that can tolerate fly-ashes with higher carbon contents must be identified.

Industry had approached us to study the use of fly-ash as a binder for iron-ore pellets. Realizing that this application is likely to be less sensitive to carbon content than conventional fly-ash applications, a decision was made to investigate the potential of flyash in this new application. The significance of this application can be seen from the fact that the U. S. Geological Survey estimated that 62 million metric tons of iron-ore pellets were produced in the US in 1998, consuming 756,000 metric tons of the current binder, bentonite clay ${ }^{2}$. This was the first attempt to reuse high-carbon fly-ashes.

The current cost of bentonite is high because it must be shipped several hundred miles from the Western United States (e. g., Wyoming) to the iron ore concentrate pellet producing region of Minnesota and Michigan's Upper Peninsula. Fly-ash has the benefit of being produced by power plants located within a few miles of iron ore pelletizing plants, and so shipping costs are correspondingly lower.

Bentonite is an expandable clay composed of the mineral montmorillonite. It bonds the magnetite concentrate particles by absorbing water and dispersing into a gel that physically bonds the particles together. In contrast, fly-ash is a pozzolan composed of alumino-silicates. Pozzolans chemically react with lime and water to form bonding calcium silicates, a reaction commonly associated with the formation of concrete.

Once magnetite pellets are formed and dried, they are hardened by induration. The term "indurate" is used interchangeably with the term "sinter" and "fire" in industrial practice. Induration occurs when heat causes particles in the pellet to bond together more strongly than the relatively weakly bonded dry pellets. Induration bonding occurs either from diffusion across particle to particle contact points, forming a grain boundary, or from melting or softening of a phase, such as gangue or binder, that solidifies into a strong matrix. Preliminary work at MTU has shown that fly-ash is a suitable replacement for

1. The Fly Ash Resource Center (1999), Coal Combustion By-Products, available by World-WideWeb, http://www.geocities.com/CapeCanaveral/Launchpad/2095/flyash.htm 2. USGS (1999), Mineral Commodity Summaries, available by World-Wide-Web, http://minerals.er.usgs.gov:80/minerals/pubs/mcs/ 
bentonite in this application and that the carbon content of the fly-ash does not affect pellet quality. In fact, higher carbon content decreases fuel consumption during pellet induration.

This work began when an iron ore pellet producer approached us to study the use of flyash as a pellet-binder, which demonstrates an industrial interest for this technology. The primary concern is that pellets produced during preliminary work had barely sufficient dry compressive strengths. Additional work was needed to increase the dry strengths to assure acceptance of this technology by the iron ore pellet producers. To achieve this goal, an activator and hardening accelerators were employed.

Preliminary pelletization studies showed that fly-ash in combination with calcium hydroxide could be used to produce pellets with satisfactory strength, but that the hardening speed of the binder was too slow unless hardening accelerators, such as calcium chloride, were added. Chloride salts have a detrimental effect since chlorine can potentially erode pellet processing equipment. Therefore, there was a strong need to develop non-chloride accelerators, based on improved understanding of the binding mechanisms of fly-ash.

\section{THEORETICAL DISCUSSION}

Fly-ash can be defined as a pozzolan. A pozzolanic material is composed of aluminosilicates that react with lime or calcium hydroxide in the presence of water to form calcium silicates. These reactions are essentially the same as the reactions that occur in Portland cement when it hardens to form concrete; fly-ash is often added as an admixture to cement, improving the mechanical properties of the concrete. A literature search focusing on Portland cement reactions was performed to identify chemicals that would accelerate the fly-ash activated with calcium hydroxide activator (Helmuth, 1987; Taylor, 1990). Calcium chloride was the most commonly cited accelerator, but indications were found that calcium acetate and calcium nitrate could also be used as Portland cement accelerators. Therefore, these chemicals were studied during this project as fly-ash binder accelerators.

Accelerators such as calcium chloride have been studied in cement and concrete reactions for over one hundred years. These reactions are essentially the same as fly-ash pozzolanic reactions which have also been studied, since fly-ash is often added as an admixture to concrete. The normal hardening of cement is the result of continuous calcium silicate dissolution resulting in precipitation of the gluing agent dicalcium silicate hydrate. As calcium chloride exothermically dissolves, hydration reactions are accelerated by increased temperature and because the lime that is present has a higher solubility in the lower $\mathrm{pH}$ calcium chloride solutions than in water (Platzmann, 1926); the lower $\mathrm{pH}$ also results in accelerated dissolution of the calcium silicates. Then, the hydrate is more rapidly precipitated from increased calcium ion concentration available from the calcium chloride and dissolved calcium hydroxide (Forsen, 1938). Finally, the calcium chloride retains water throughout the reaction allowing the reaction to continue longer. Calcium chloride addition accelerates the formation of tricalcium silicates, dicalcium silicates, and tricalcium aluminates and increases the calcium oxide/silicon dioxide $\left(\mathrm{CaO} / \mathrm{SiO}_{2}\right)$ ratio of the calcium-silicate-hydrate (C-S-H) phase (Odler and Abdul-Maula, 1987). Furthermore, the lime hydration reaction is exothermic and increases the reaction temperature 
proportional to the concentration, thereby also accelerating the hardening reaction kinetics.

\section{EXPERIMENTAL PROCEDURES}

\section{$\underline{\text { Materials }}$}

The material pelletized in these experiments was magnetite $\left(\mathrm{Fe}_{3} \mathrm{O}_{4}\right)$ concentrate $(10 \%$ moisture), provided by the Cleveland Cliffs Iron Company, Cleveland, Ohio. Approximately $400 \mathrm{~kg}(880 \mathrm{lb})$ of magnetite was divided into samples of approximately $3.5 \mathrm{~kg}(8 \mathrm{lb})$ by coning and quartering, and the individual samples were sealed into plastic bags to prevent moisture losses.

Table 1: Chemical analyses of the three Edwards fly-ashes in their raw state and the Allied Colloids SPV 200 bentonite. Analysis ranges from 17 typical Western Bentonites used in a pelletizing plant are also included for comparison. Bentonite is the material currently used as a particulate binder.

\begin{tabular}{|c|c|c|c|c|c|}
\hline $\begin{array}{c}\text { Analyte } \\
(\%)\end{array}$ & $\begin{array}{c}\text { Edwards } \\
\text { Unit 1 }\end{array}$ & $\begin{array}{c}\text { Edwards } \\
\text { Unit 2 }\end{array}$ & $\begin{array}{c}\text { Edwards } \\
\text { Unit 3 }\end{array}$ & $\begin{array}{c}\text { SPV 200 } \\
\text { Bentonite }\end{array}$ & $\begin{array}{c}\text { Western } \\
\text { Bentonite } \\
\text { Low-High }\end{array}$ \\
\hline \hline $\mathrm{SiO}_{2}$ & 51.67 & 38.87 & 42.24 & 34.62 & $44.35-63.60$ \\
\hline $\mathrm{Al}_{2} \mathrm{O}_{3}$ & 26.26 & 22.92 & 24.68 & 23.16 & $18.37-20.59$ \\
\hline $\mathrm{Fe}_{2} \mathrm{O}_{3}$ & 10.41 & 6.09 & 8.76 & 5.49 & $4.0-5.0$ \\
\hline $\begin{array}{c}\text { Total }\left(\mathrm{SiO}_{2}+\mathrm{Al}_{2} \mathrm{O}_{3}\right. \\
\left.+\mathrm{Fe}_{2} \mathrm{O}_{3}+\mathrm{TiO}_{2}\right)\end{array}$ & 88.33 & 67.88 & 75.67 & 63.26 & $66.85-89.35$ \\
\hline $\mathrm{CaO}$ & 3.12 & 15.11 & 11.11 & 9.63 & $1.34-4.35$ \\
\hline $\mathrm{MgO}$ & 0.99 & 3.56 & 2.39 & 2.11 & $1.75-3.80$ \\
\hline $\mathrm{Na}_{2} \mathrm{O}$ & 0.62 & 1.71 & 1.25 & 1.06 & $1.32-3.00$ \\
\hline $\mathrm{K}_{2} \mathrm{O}$ & 2.59 & 0.994 & 1.60 & 0.39 & $0.28-0.96$ \\
\hline $\mathrm{TiO}_{2}$ & 1.31 & 1.18 & 1.25 & 1.25 & $0.13-0.16$ \\
\hline $\mathrm{MnO}_{2}$ & 0.06 & 0.05 & 0.08 & 0.01 & $0.004-0.02$ \\
\hline $\mathrm{P}_{2} \mathrm{O}_{5}$ & 0.15 & 0.91 & 0.55 & 2.20 & $0.14-0.19$ \\
\hline $\mathrm{SrO}_{\mathrm{BaO}}$ & 0.15 & 0.20 & 0.27 & 0.39 & $\sim 0.00$ \\
\hline $\mathrm{SO}_{3}$ & 0.17 & 0.48 & 0.33 & 0.53 & $\sim 0.01$ \\
\hline $\mathrm{LOI}$ & 0.66 & 1.20 & 1.13 & 5.93 & $0.47-1.00$ \\
\hline
\end{tabular}

One sample of bentonite and three samples of fly-ash were obtained for use as binders. The fly-ashes were collected from three separate units at the Central Illinois Light Company's (CILCo) E. D. Edwards power plant that were designated as Unit 1, 2, and 3 fly-ashes. Approximately $35 \mathrm{~kg}(75 \mathrm{lb})$ of each fly-ash was thoroughly mixed and divided into representative samples of approximately 750 grams $(1.7 \mathrm{lb})$ by coning, quartering, 
and incremental sampling. Then, the individual samples were sealed into plastic bags. The sample of bentonite clay was obtained from Allied Colloids Limited. Quantitative elemental analysis was performed with XRF on the bentonite and fly-ashes by a commercial testing firm specializing in fly-ash analysis. Chemical analyses of the Edward's plant ashes are compared in Table 1 with a range of typical western bentonites. Chemical analysis was performed with by x-ray diffraction. Particle size was determined both by screening and laser diffraction (Microtrac).

Reagent grade calcium hydroxide $\left[\mathrm{Ca}(\mathrm{OH})_{2}\right]$, calcium acetate $\left[\mathrm{Ca}\left(\mathrm{C}_{2} \mathrm{H}_{3} \mathrm{O}_{2}\right)_{2} \cdot \mathrm{H} 2 \mathrm{O}\right]$, calcium nitrate $\left[\mathrm{Ca}\left(\mathrm{NO}_{3}\right)_{2} \cdot 4 \mathrm{H}_{2} \mathrm{O}\right]$, and calcium chloride dihydrate $\left[\mathrm{CaCl} 2 \cdot 2 \mathrm{H}_{2} \mathrm{O}\right]$ were used.

\section{Equipment}

Binder components were mixed together with a Spex mixer/mill (Spex Industries, Inc., New Jersey, USA). The binder was mixed into the concentrate with a Readco Type-A kneader-mixer. Pellets were formed with a laboratory-scale balling drum, shown schematically in Figure 1. Pellets were dried in a Blue M (Illinois, USA) drying oven. Pellets were fired in a Thermolyne Type 46100 high temperature furnace. Ultimate compressive strengths of the pellets were determined with an Instron 4206 using an 8896 newton (2000 lbf) load cell at a constant cross-head speed of $40 \mathrm{~mm} / \mathrm{min}$. (1.57 in/min.). X-ray diffraction was performed with a Scintag, Inc. XDS $2000 \Theta / \Theta$ diffractometer and data were analyzed with DMSNT version 1.33 software.

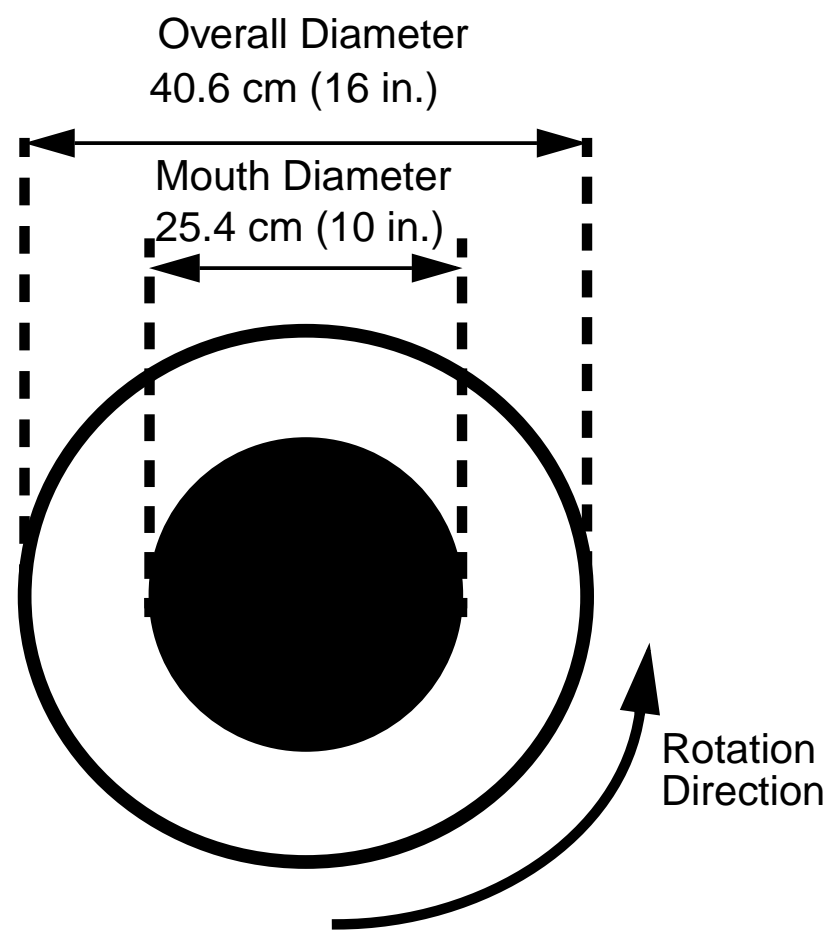

Figure 1. Dimensions of the laboratory-scale pelletizing drum used for iron ore pellet production. The $17.8 \mathrm{~cm}$ (7 in.) deep steel drum rotated at $25 \mathrm{rpm}$. Feed and water spray was added and pellets were removed through the mouth. 


\section{$\underline{\text { Procedure }}$}

Before adding the binder to the magnetite, the desired quantities of fly-ash, calcium hydroxide, and accelerator were weighed out and mixed using a Spex mixer/mill for 5 minutes to ensure that the components were thoroughly mixed. The binder mixture was then slowly added to the magnetite in a kneader-mixer, and mixed at $350 \mathrm{rpm}$ with a 150 rpm orbital motion for 5 minutes.

The procedure used for forming the pellets was developed by industry to closely reproduce the conditions that exist in the full-scale plant. The mixed material was delumped through an $2.36 \mathrm{~mm}(8 \mathrm{mesh})$ screen before pelletizing. A small amount of the material was then added to the pelletizing drum (rotating at $25 \mathrm{rpm}$ ) to create pellet "seeds". The seeds were moistened with water mist while adding additional material to enlarge them into pellets. The pellets were removed from the drum periodically, and screened to control the pellet diameter. This procedure was continued until 1-2 $\mathrm{kg}(2-5 \mathrm{lb})$ of finished pellets, screened between $12.7 \mathrm{~mm}$ and $11.2 \mathrm{~mm}$ in diameter $(1 / 2 \mathrm{x} 7 / 16 \mathrm{inch}$ in diameter) were produced for testing. The time required for pelletization was 20 minutes. The finished pellets were then immediately dried at $105^{\circ} \mathrm{C}\left(220^{\circ} \mathrm{F}\right)$, and held at this temperature for 20 to 24 hours to ensure that they were completely dried. 
The pellets were tested using the procedures given in Table 2.

Table 2: Descriptions of the tests used for evaluating pellet quality.

\begin{tabular}{|c|l|l|}
\hline Test & \multicolumn{1}{|c|}{ Procedure } & \multicolumn{1}{|c|}{ Use of Data } \\
\hline \hline Wet-knock & $\begin{array}{l}\text { A single freshly-made (undried) pellet is } \\
\text { dropped repeatedly from a height of 45.7 } \\
\text { cm (18 inches) onto a steel plate. For 20 } \\
\text { pellets, the average number of drops } \\
\text { required for fracture is recorded. }\end{array}$ & $\begin{array}{l}\text { Measures the ability of the } \\
\text { wet pellet to remain intact } \\
\text { during handling. }\end{array}$ \\
\hline Wet-crush & $\begin{array}{l}\text { A single (undried) pellet is compressed } \\
\text { using an Instron compression test machine } \\
\text { with a crosshead speed of } 40 \text { mm/min. For }\end{array}$ & $\begin{array}{l}\text { Measures the ability of the } \\
\text { wet pellets to retain their } \\
\text { shape during handling }\end{array}$ \\
\hline $\begin{array}{c}\text { Dry-crush pellets, the average load required to } \\
\text { fracture the pellet is recorded. }\end{array}$ & $\begin{array}{l}\text { Pellets are dried at } 105^{\circ} \mathrm{C}\left(221^{\circ} \text { F) for at }\right. \\
\text { least 1 hour, and single pellets are then } \\
\text { compressed using an Instron compression } \\
\text { test machine. For } 20 \text { pellets, the average } \\
\text { load required to fracture the pellet is } \\
\text { recorded. }\end{array}$ & $\begin{array}{l}\text { Measures the ability of } \\
\text { dried pellets to survive } \\
\text { handling during the firing } \\
\text { process. Should be at least } \\
22.4 \text { newtons (5 pounds } \\
\text { force) per pellet. This is the } \\
\text { most critical measurement. }\end{array}$ \\
\hline $\begin{array}{c}\text { Fired- } \\
\text { crush } \\
\text { (sintered } \\
\text { or } \\
\text { indurated } \\
\text { crush) }\end{array}$ & $\begin{array}{l}\text { Pellets are added to a furnace and preheated } \\
\text { for 15 minutes as the temperature rises } \\
\text { from ambient to } 1200^{\circ} \mathrm{C} \text {, where the } \\
\text { temperature is held for 10 minutes. } \\
\text { Individual pellets are then compressed } \\
\text { using an Instron compression test machine. } \\
\text { For 20 pellets, the average load required to } \\
\text { fracture the pellet is recorded. }\end{array}$ & $\begin{array}{l}\text { Measures the ability of } \\
\text { sintered pellets to survive } \\
\text { during shipping, handling, } \\
\text { and blast furnace loading. }\end{array}$ \\
$\begin{array}{l}\text { Should be at least 1780 } \\
\text { newtons (400 pounds force) } \\
\text { per pellet. }\end{array}$ \\
\hline
\end{tabular}

For each value reported, the mean and standard deviation were determined for 20 pellets. The $95 \%$ confidence interval $\left(\mathrm{P}_{95}\right)$ is the range within which there is $95 \%$ certainty that the true mean for the entire batch of pellets lies. This value is calculated using the tdistribution, as described in standard statistics texts (Dixon and Massey, 1983). For 20 pellets (19 degrees of freedom), the $95 \%$ confidence interval is calculated from the measured standard deviation using the relationship:

$$
P_{95}= \pm\left(\frac{t_{95}(19)}{\sqrt{N}}\right) s= \pm(0.386) s
$$

$\begin{array}{rlrl}\text { where } & \mathrm{s}= & & \text { measured standard deviation for the data set } \\ \mathrm{N}= & & \text { number of data points (equal to } 20 \text { for the procedures used here) } \\ \mathrm{t}_{95}(19)= & & \text { the } \mathrm{t} \text {-value for the } 95 \% \text { confidence interval, at } 19 \text { degrees of freedom } \\ \mathrm{P}_{95}= & 95 \% \text { confidence interval for the mean calculated for the data set. }\end{array}$




\section{RESULTS AND DISCUSSION}

The results from the laser diffraction size analyses are shown in Figure 2. Each material has a similar size distribution with $80 \%$ passing sizes ranging from 20 microns for the magnetite concentrate to 55 microns for the Unit 2 fly-ash.

\section{Microtrac Size Analyses}

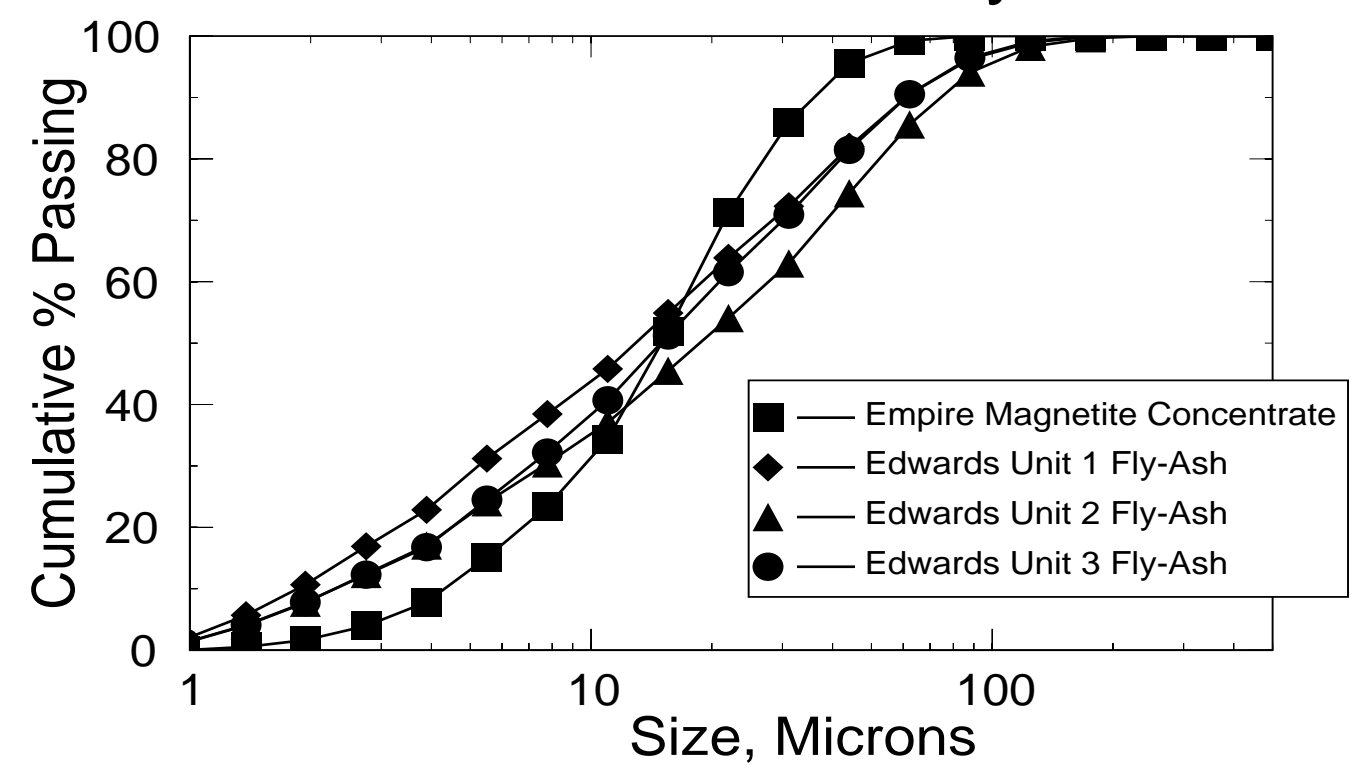

Figure 2. Laser diffraction size analyses of the Empire magnetite concentrate and Illinois fly-ashes performed with a Leeds and Northrup Microtrac SRA, verified with wet sieving.

Figure 3 shows the x-ray diffraction (XRD) pattern for the unit 2 fly-ash, which was essentially identical to the Unit 1 and Unit 3 fly-ash patterns. Peak positions reveal that the fly-ashes are composed of quartz $\left(\mathrm{SiO}_{2}\right)$, mullite $\left(\mathrm{Al}_{6} \mathrm{Si}_{2} \mathrm{O}_{13}\right)$, and maghemite $\left(\mathrm{Fe}_{2} \mathrm{O}_{3}\right)$. The high background is due to a "diffuse" peak, which reveals that a large portion of the fly-ash is amorphous. The amorphous phase(s) are expected to be alumino-silicate glass.

Figure 4 shows the XRD pattern for the unreacted Unit 2 fly-ash based binder (FBB). The binder contains an amorphous phase, quartz from the fly-ash, calcium hydroxide (portlandite, $\mathrm{Ca}(\mathrm{OH})_{2}$ ) from the activator, and hydrated calcium chloride as calcium chloride hydroxide hydrate $\left(\mathrm{CaCl}_{2} \cdot \mathrm{Ca}(\mathrm{OH})_{2} \cdot \mathrm{H}_{2} \mathrm{O}\right)$.

The unreacted FBB was then mixed at proper concentrations with water in a spex mixer for 5 minutes and dried thoroughly. The XRD pattern for the reacted FBB (shown in Figure 5) reveals that the concentration of calcium chloride and calcium hydroxide are decreased. This is explained according to Helmuth (1987), in that amorphous aluminosilicate material reacted with the calcium chloride and calcium hydroxide to form an amorphous calcium silicate hydrate gel.

Figures 6 and 7 reveals that XRD scans are essentially the same for dry pellets with either binder. This is because the binder dosage is very small at $0.66 \%$ by magnetite concentrate 
weight. Figure 8 shows that essentially all of the magnetite is oxidized to hematite during induration.

Unit 2 Fly-Ash

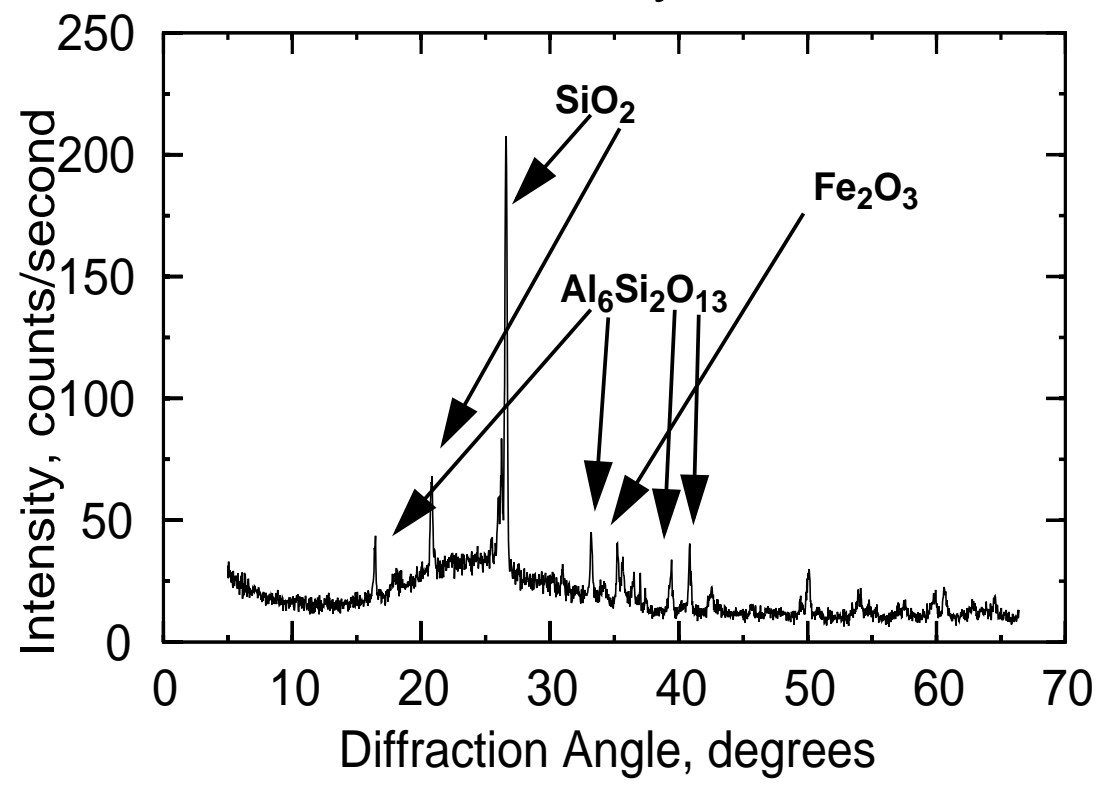

Figure 3. X-ray diffraction (XRD) pattern for CILCO's Edwards Unit 2 flyash showing the presence of a glassy phase with crystalline quartz, mullite, and maghemite.



Figure 4. XRD pattern for unreacted Unit 2 fly-ash based binder (FBB) showing the presence of a glassy phase with crystalline quartz, calcium chloride and calcium hydroxide. 


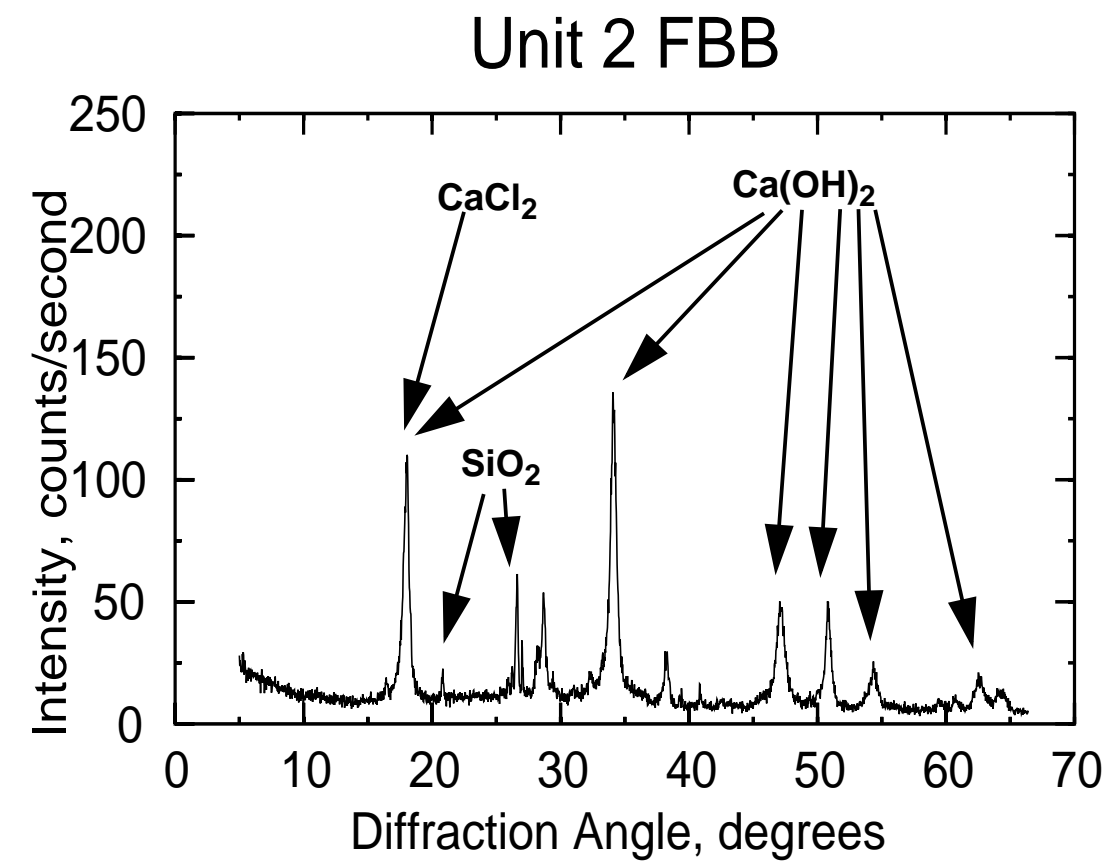

Figure 5. XRD pattern for reacted Unit $2 \mathrm{FBB}$ showing the presence of a glassy phase with crystalline quartz. Some calcium chloride and calcium hydroxide has reacted.

Dry Pellet - FBB

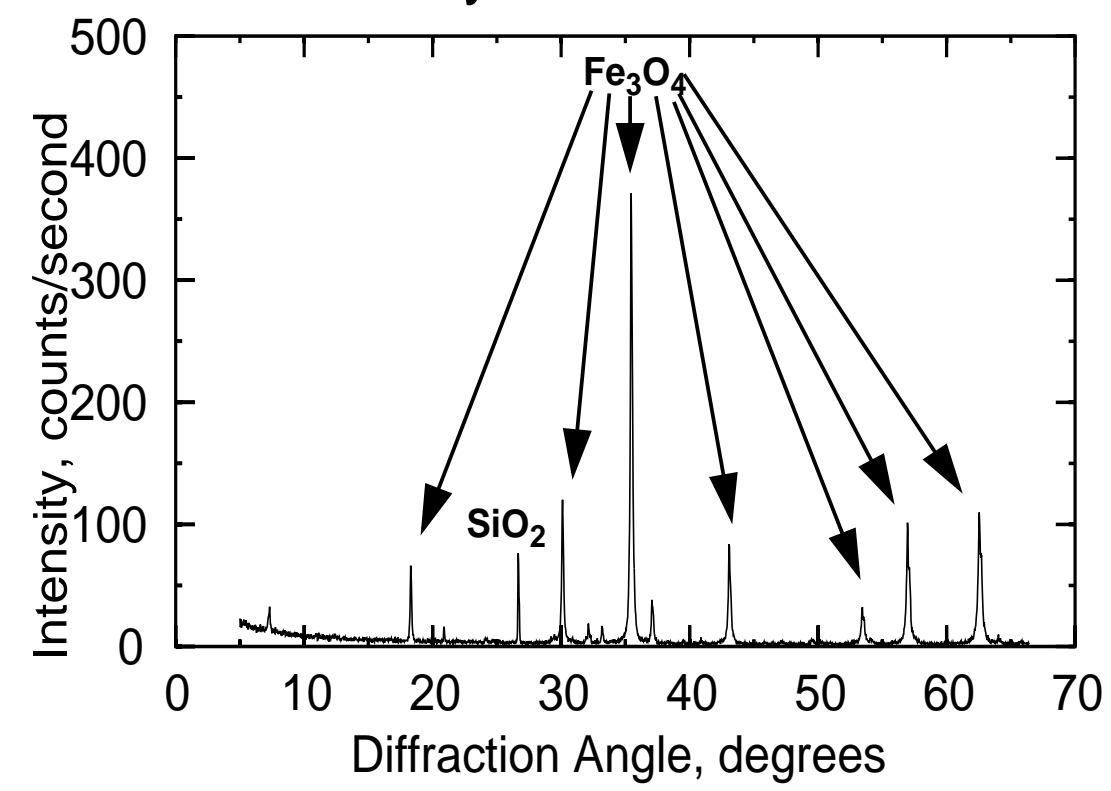

Figure 6. XRD pattern for a FBB bonded magnetite pellet, essentially entirely composed of crystalline quartz and magnetite. 


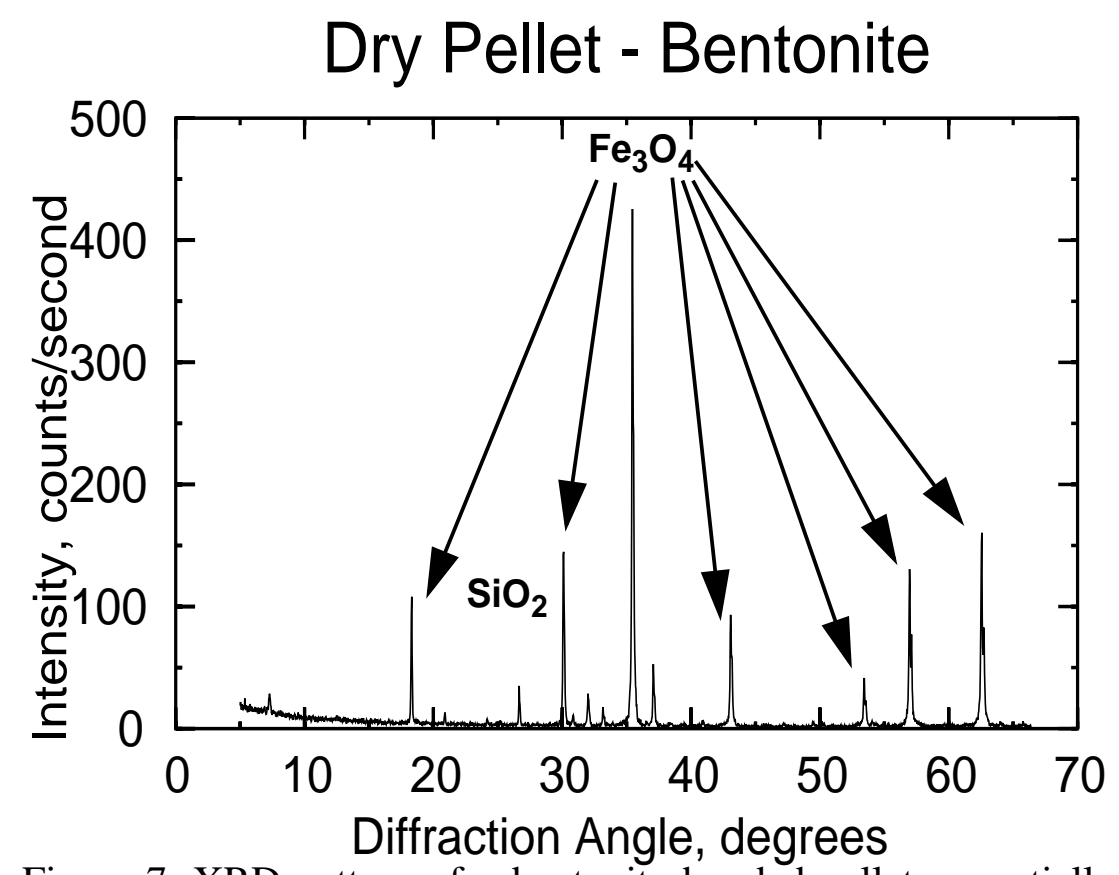

Figure 7. XRD pattern of a bentonite bonded pellet, essentially entirely composed of crystalline quartz and magnetite.

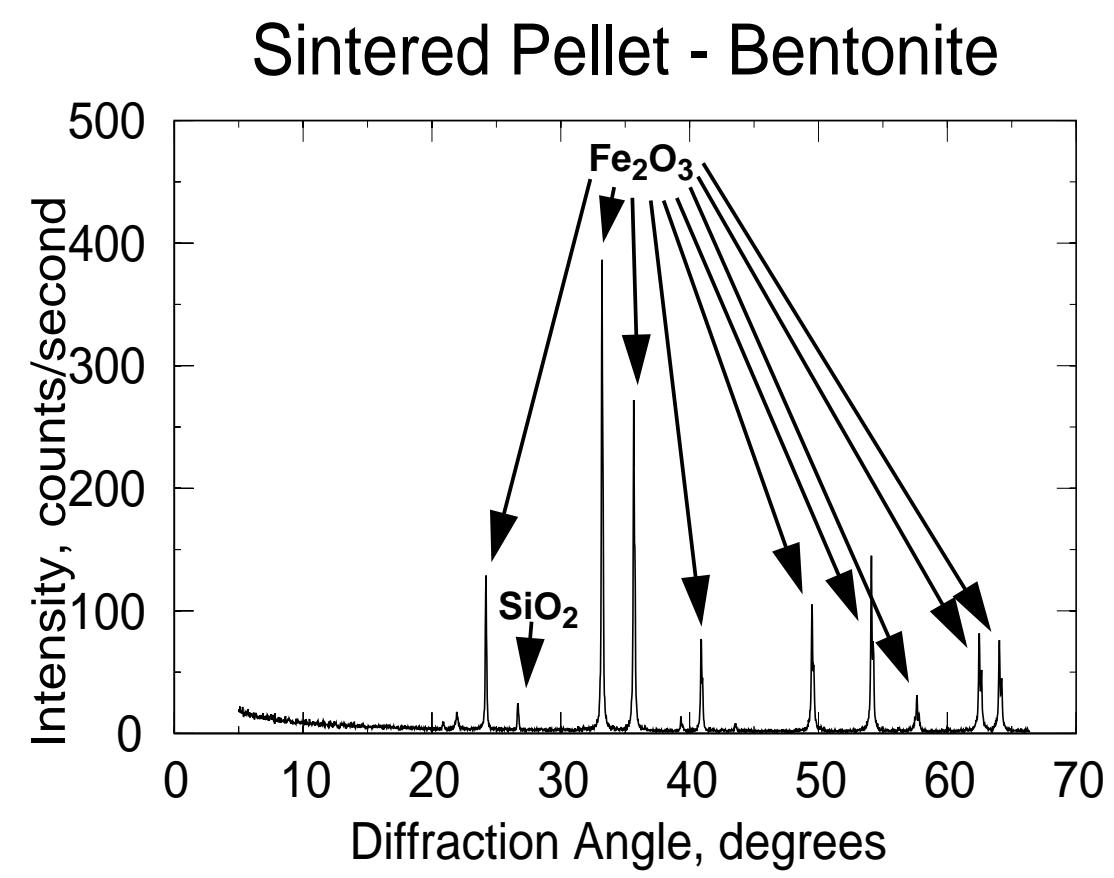

Figure 8 . XRD pattern of a sintered bentonite bonded pellet, essentially entirely composed of crystalline quartz and hematite. 
A series of pelletization tests were completed using fly-ash dosages of $0.66 \%$ and $1.5 \%$ by weight of the magnetite. Calcium hydroxide dosage varied between $0.0 \%$ and $1.0 \%$ of the total magnetite weight and the dosages of the calcium acetate, calcium nitrate, and calcium chloride accelerators varied between $0.0 \%$ and $0.2 \%$ of the total magnetite concentrate weight. The wet knock results, shown in Figure 9, reveal that addition of

\section{Fly-Ash Bonded Magnetite Pellets}

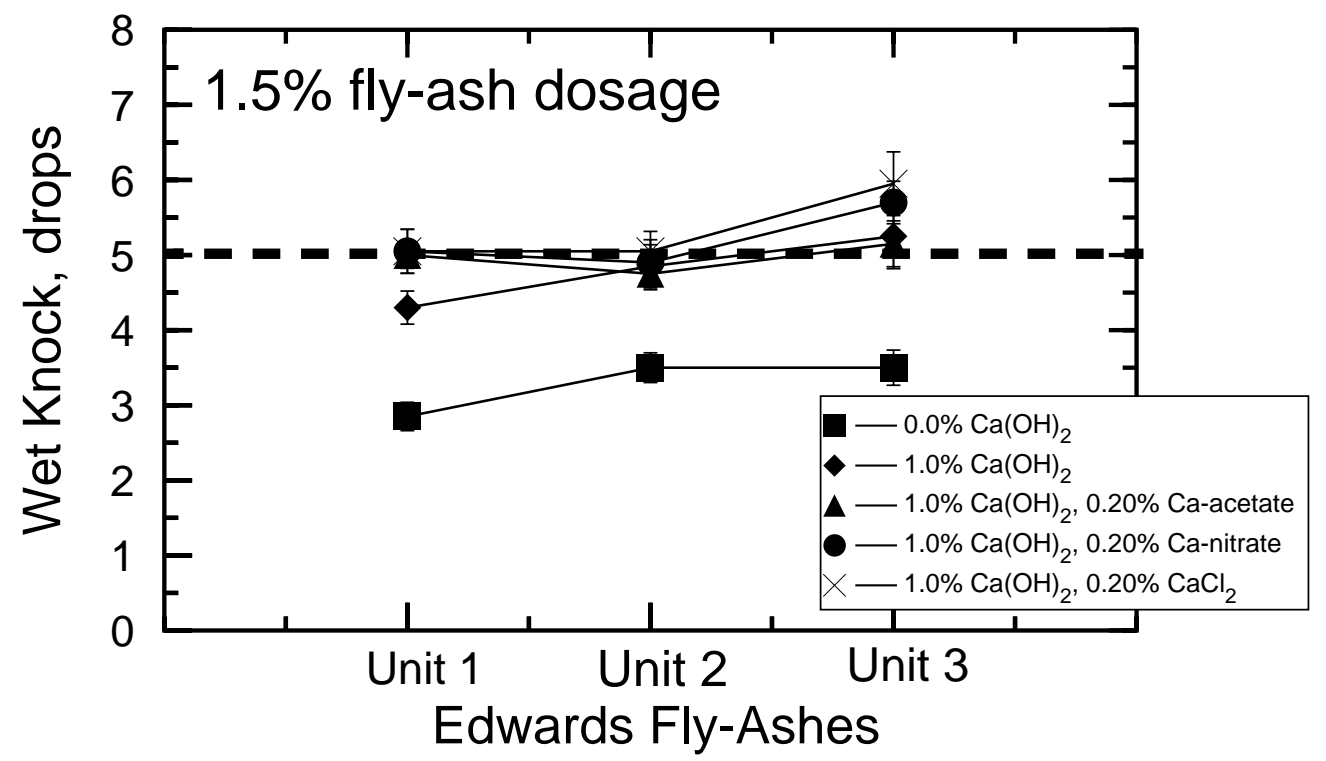

Figure 9. Strength of magnetite concentrate pellets bonded with fly-ash based binders at various activator (calcium hydroxide) and accelerator additions. Pellet strengths are the number of $45.7 \mathrm{~cm}$ drops onto a steel plate that a 12.7 $\mathrm{mm}$ diameter pellet endures before fracture. Dosages are expressed as percentages of the total iron ore concentrate weight. Fly-ash dosage was held constant at $1.5 \%$. Each point is the average over 20 measurements, and the error bars are for the $95 \%$ confidence interval. The pellets had increasing wet knocks from calcium hydroxide addition, while little effect is shown from accelerator addition, for this stage of testing. The heavy dashed line represents the minimum industrially acceptable wet knock value of 5 drops.

calcium hydroxide to fly-ash based binders was important to allow the wet pellets to survive industrial handling. Addition of accelerators showed little benefit for this stage of testing. The dry-crush strength results from these tests, given in Figure 10 reveal that calcium hydroxide is important for improving the dry strength of fly-ash bonded magnetite concentrate pellets. These results also demonstrate that calcium acetate, calcium nitrate, and calcium chloride were each acceptable accelerators that improved the pellet strengths significantly. The addition of any of the three accelerators resulted in industrially acceptable pellet strengths. 


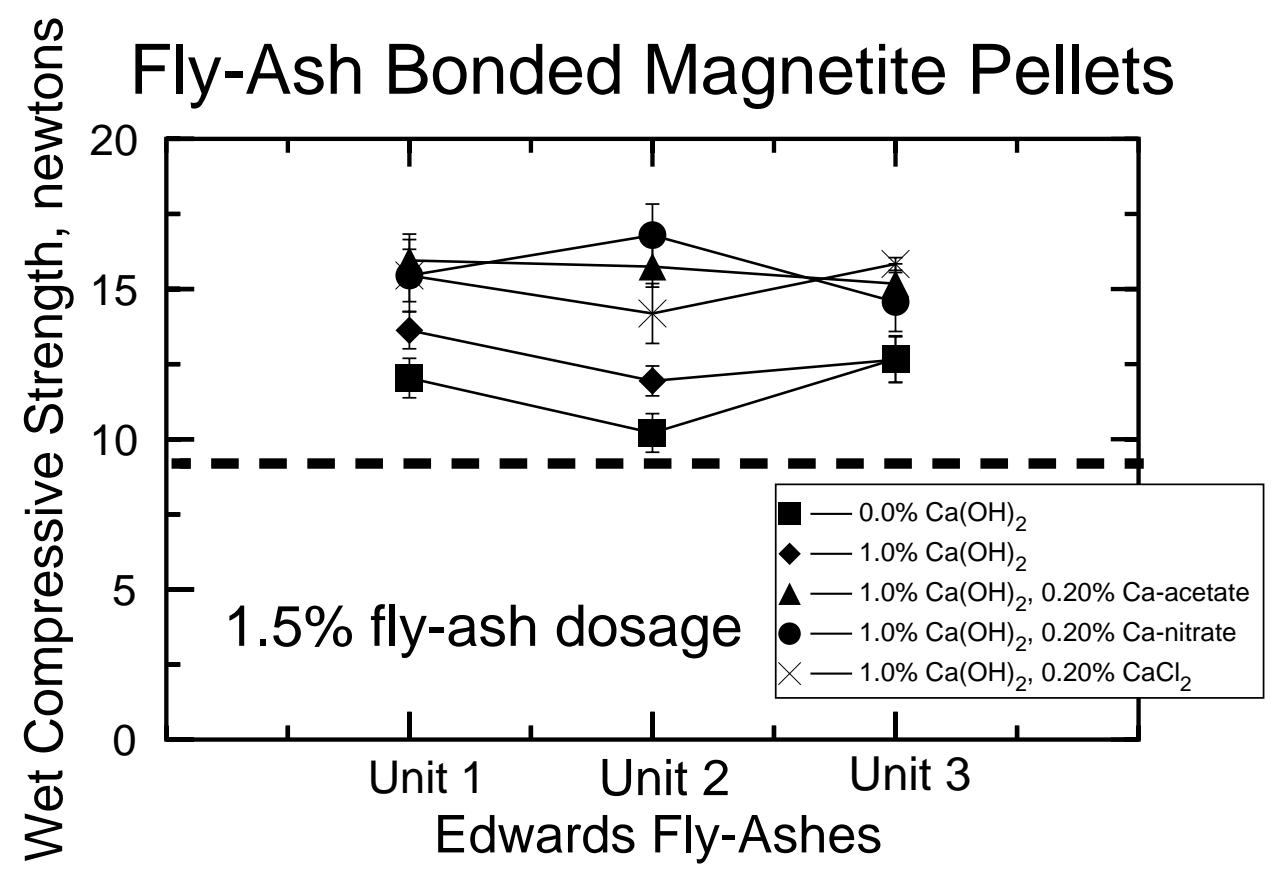

Figure 10. Strength of wet magnetite concentrate pellets bonded with fly-ash based binders at various activator (calcium hydroxide) and accelerators additions. Pellet strengths are the load in newtons per $12.7 \mathrm{~mm}$ diameter pellet needed to fracture the pellet. Dosages are expressed as percentages of the total iron ore concentrate weight. Fly-ash dosage was held constant at $1.5 \%$. Each point is the average over 20 measurements, and the error bars are for the $95 \%$ confidence interval. The pellets had increasing wet compressive strengths from calcium hydroxide addition that increased further with accelerator addition. The heavy dashed line represents the minimum industrially acceptable wet compressive strength value of 9 newtons.

Dry compressive strength is the most important criteria for measuring the quality of an iron ore pellet binder, and the most difficult to achieve. The results shown in Figure 11 reveal that calcium hydroxide addition is required to produce acceptable quality fly-ash bonded iron ore pellets. In addition, either of the three accelerators significantly improve the dry pellet strength. The figure also shows that pellet strength is not dependent of carbon content in the range of $1.84 \%$ to $6.87 \%$ and that high carbon fly-ash based binder can be used for iron ore pellets.

Finally, the fly-ash dosage was decreased to a standard bentonite concentration of $0.66 \%$. The effect of fly-ash dosage, shown in Figure 12, reveals that while the iron ore pellets had reduced strength with reduced fly-ash addition, the pellets still had acceptable strengths.

The effect of fly-ash addition is shown in Figure 13. Addition of fly-ash was as important for increasing the pellet strengths as accelerator addition, showing that fly-ash does play a major role within the fly-ash based binders.

Induration (sintering) tests were performed on selected types of pellets that had acceptable strengths. Table 3 lists the strengths of the pellets that were tested. The binder consisting 


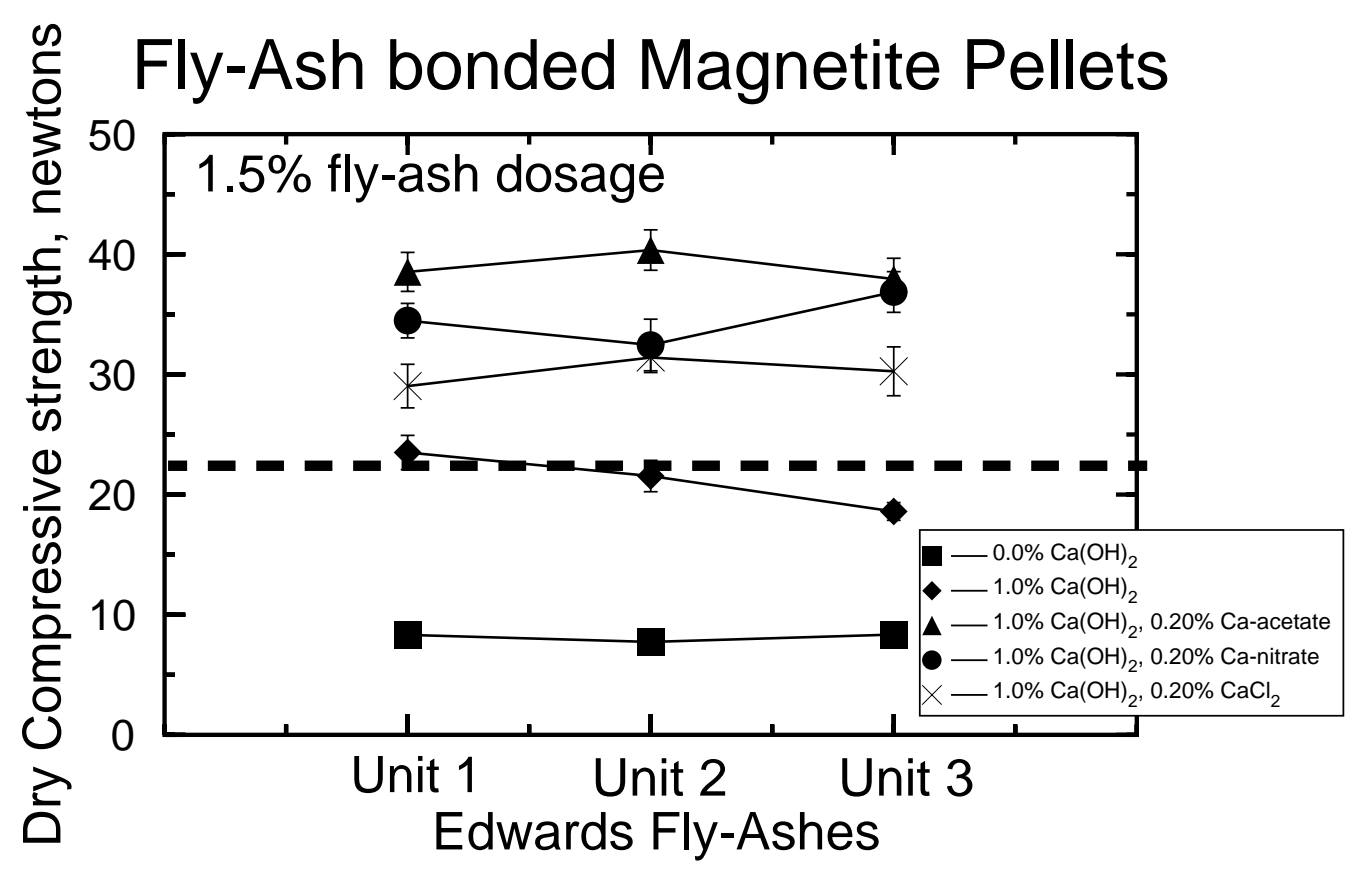

Figure 11. Strength of dry magnetite concentrate pellets bonded with fly-ash based binders at various activator (calcium hydroxide) and accelerators additions. Pellet strengths are the load in newtons per $12.7 \mathrm{~mm}$ diameter pellet needed to fracture the pellet. Dosages are expressed as percentages of the total iron ore concentrate weight. Fly-ash dosage was held constant at 1.5\%. Each point is the average over 20 measurements, and the error bars are for the $95 \%$ confidence interval. The pellets had increasing dry compressive strengths from calcium hydroxide addition that increased further with accelerator addition. The heavy dashed line represents the minimum industrially acceptable dry compressive strength value of 22.2 newtons.

of $1.5 \%$ fly-ash and calcium acetate or calcium chloride as accelerator resulted in pellets of superior strength to those of the bentonite bonded pellets. The $0.66 \%$ high carbon flyash pellets had slightly weaker fired compressive strengths than the bentonite pellets, but they are still acceptable according to industrial standards.

Table 3: Results of compression tested indurated pellets. The minimum industrially accepted values for fired crush strength is 1780 Newtons (400 lbf).

\begin{tabular}{|c|c|c|c|c|c|}
\hline \multirow[t]{2}{*}{ Binder } & \multirow[t]{2}{*}{$\begin{array}{c}\text { Binder } \\
\text { dosage, } \%\end{array}$} & \multirow[t]{2}{*}{$\begin{array}{r}\mathrm{Ca}(\mathrm{OH})_{2} \\
\text { dosage, \% }\end{array}$} & \multirow[t]{2}{*}{$\begin{array}{l}\text { Accelerator at } \\
0.2 \% \text { dosage }\end{array}$} & \multicolumn{2}{|c|}{$\begin{array}{l}\text { Fired Crush } \\
\text { Strengths, newtons } \\
\text { per pellet }\end{array}$} \\
\hline & & & & mean & $\mathrm{P}_{95}$ \\
\hline Bentonite & 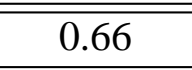 & none & "none & 2320 & 130 \\
\hline Unit 2 fly-ash & 1.5 & 1.0 & calcium acetate & 3100 & 310 \\
\hline Unit 2 fly-ash & 1.5 & 1.0 & calcium chloride & 2900 & 320 \\
\hline Unit 2 fly-ash & 0.66 & 1.0 & calcium acetate & 1840 & 100 \\
\hline
\end{tabular}






Figure 12. Strength of magnetite concentrate pellets bonded with fly-ash based binders at various fly-ash and accelerators additions. Pellet strengths are the load in newtons per $12.7 \mathrm{~mm}$ diameter pellet needed to fracture the pellet. Dosages are expressed as percentages of the total iron ore concentrate weight. Calcium hydroxide dosage was held constant at $1.0 \%$. Each point is the average over 20 measurements, and the error bars are for the $95 \%$ confidence interval. The pellets had reduced, but still acceptable, dry compressive strengths from fly-ash dosage reduction. The heavy dashed line represents the minimum industrially acceptable dry compressive strength value of 22.2 newtons. 


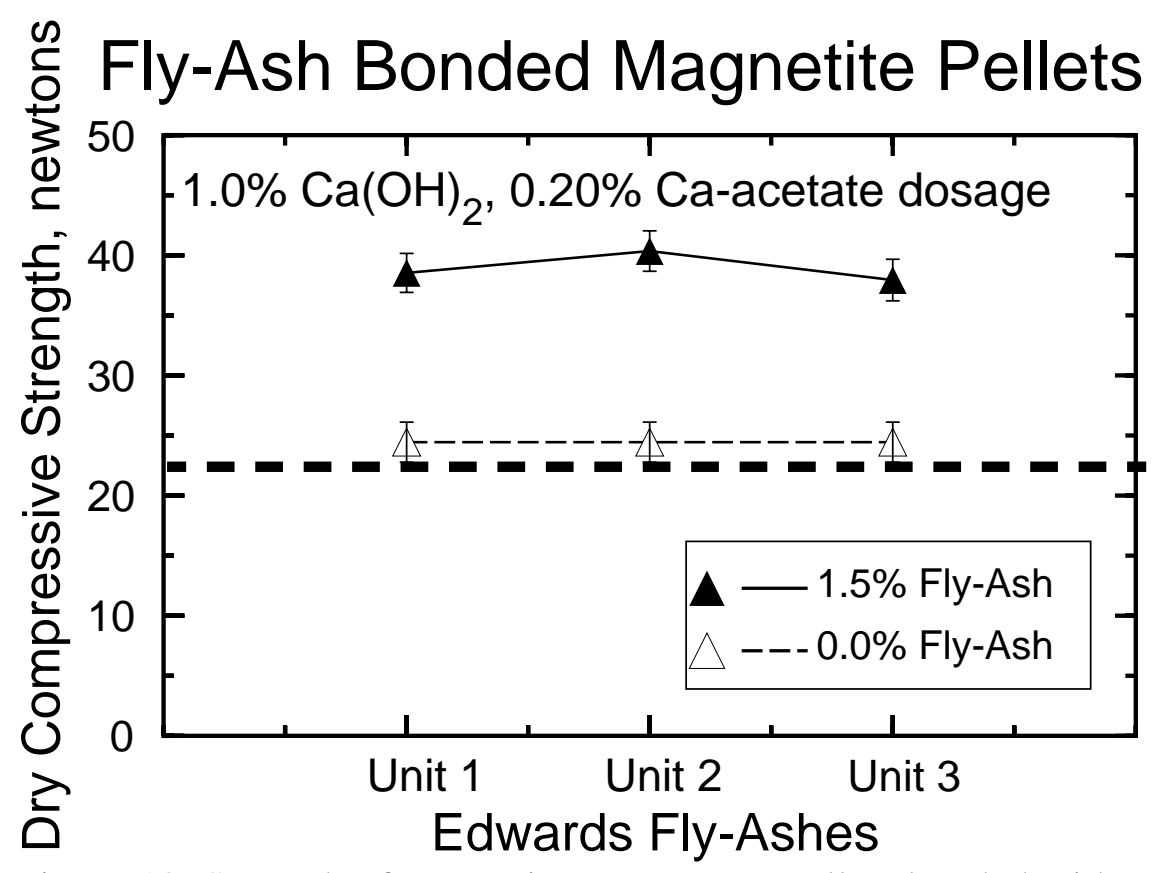

Figure 13. Strength of magnetite concentrate pellets bonded with and without fly-ash, with $1.0 \%$ calcium hydroxide and $0.20 \%$ calcium acetate. Pellet strengths are the load in newtons per $12.7 \mathrm{~mm}$ diameter pellet needed to fracture the pellet. Dosages are expressed as percentages of the total iron ore concentrate weight. Each point is the average over 20 measurements, and the error bars are for the $95 \%$ confidence interval. The pellets had reduced dry compressive strengths without fly-ash addition. The heavy dashed line represents the minimum industrially acceptable dry compressive strength value of 22.2 newtons.

\section{CONCLUSION}

- Iron ore pellets must be made to allow shipping and blast furnace reduction of the inherently fine U. S. iron ore concentrates. The majority or U. S. iron and steel comes from iron ore pellets.

- Magnetite concentrate pellets were made using 1.5\% fly-ash alone as binder that had insufficient strengths. This was the first attempt to reuse high-carbon fly-ash.

- Addition of $1.0 \%$ calcium hydroxide to the $1.5 \%$ fly-ash activated the binder and improved the strength of pellets to the minimum industrially acceptable values. Specifically, calcium hydroxide improved the wet knock and wet and dry compressive strength of the pellets.

- Addition of $0.2 \%$ calcium acetate, calcium nitrate, or calcium chloride hardening accelerators improved the pellet dry compressive strengths further, to well above the minimum industrially acceptable values. This demonstrates that either calcium nitrate or calcium acetate can replace the highly corrosive calcium chloride accelerator. Dry 
compressive strength is one of the most important criterion for judging the quality of a pellet binder.

- X-ray diffraction data support that pozzolanic fly-ash reacted with calcium hydroxide and accelerator which produced an amorphous calcium silicate hydrate gel.

- Pellet strength was independent of carbon content in the range of $1.84 \%$ to $6.87 \%$ and high carbon fly-ash based binder can be used for iron ore pellets.

- Fly-ash addition was decreased to $0.66 \%$ and, while the pellet strengths decreased, they still exceeded the minimum industrially acceptable values.

- Fly-ash was shown to play a significant role in the binder when it was removed and the resulting pellet strengths decreased dramatically. Addition of fly-ash to the binder was shown to be as important as accelerator addition.

- Indurated iron ore pellets made with $1.5 \%$ high carbon fly-ash and calcium acetate or calcium chloride as accelerator resulted with pellets of superior strength to those of the bentonite bonded pellets.

- Indurated iron ore pellets made with $0.66 \%$ high carbon fly-ash pellets had slightly weaker fired compressive strengths than the bentonite pellets, but still exceed industrial standards

- X-ray diffraction revealed that dry magnetite $\left(\mathrm{Fe}_{3} \mathrm{O}_{4}\right)$ pellets oxidized during sintering to form sintered hematite $\left(\mathrm{Fe}_{2} \mathrm{O}_{3}\right)$ pellets.

\section{REFERENCES}

(1) Ames, J. A., and W. E. Cutcliffe (1983) "Cement and Cement Raw Materials", Industrial Minerals and Rocks (S. J. Lefond, ed.) Society of Mining, Metallurgical, and Petroleum Engineers, pp. 133-159.

(2) ASTM (1994) "Standard Specification for Coal Fly Ash and Raw or Calcined Natural Pozzolans for Use as a Mineral Admixture in Portland Cement Concrete," Annual Book of ASTM Standards, Volume 4.02, Standard No. C 618 $94 \mathrm{a}$

(3) Behr-Andres, T. (1991) "Utilization of Industrial Coal Ash: Characterization, Market Identification, and Environmental Impact", Ph.D. Dissertation, Michigan Technological University, Houghton, MI

(4) Dixon, W. J., and Massey, F. J. (1983) Introduction to Statistical Analysis, Fourth Edition, McGraw-Hill, New York, NY, pp. 83-84, and Table A5

(5) Forsen, L. (1938), "Chemistry of Accelerators," Proceedings of Symposium on Chemistry of Cements, Stockholm

(6) Goksel, M. A. (1983) "Production of Artificial Aggregates from Fly Ash," IBA Proceedings, 18 Biennial Conference, Colorado Springs, Vol. 18, pp. 57-68

(7) Grim, R. E., and N. Guven (1978) Bentonites: Geology, Mineralogy, Properties, and Uses, Elsevier, Amsterdam 
(8) Helmuth, R. (1987), Fly Ash in Cement and Concrete, Portland Cement Association, Skokie, IL

(9) Hemmings, R. T., and E. E. Berry (1985) "Speciation in Size and Density Fractionated Fly Ash," Fly Ash and Coal Conversion By-Products: Characterization, Utilization, and Disposal II, (McCarthy, Glasser, and Roy, eds.) Materials Research Society Symposium Proceedings, Volume 65, pp. 91-104

(10) Kawano, M. and Tomita, K. (1994) "Growth of Smectite from Leached Layer during Experimental Alteration of Albite," Clays and Clay Minerals, Vol. 42, No. 1, pp 7-17

(11) Mehrotra, V. P., and D. W. Fuerstenau (1981) "Production of Lightweight Aggregates by Pelletizing Lime - Fly Ash Mixtures," IBA Proceedings, 17th Biennial Conference, Reno, Nevada, Vol. 17, pp. 213-227

(12) Odler, I. and S. Abdul-Maula (1987), "Effect of Chemical Admixtures on Portland Cement Hydration," Cement and Concrete Aggregates, Vol. 9, No. 1, Summer, pp. 38-43

(13) Platzmann, C. R. (1926), "Effect of Calcium Chloride on Cement," Rock Products, Feb. 6

(14) Querol, X., A. Alastuey, J. L. Fernandez-Turiel, and A. Lopez-Soler (1995) "Synthesis of Zeolites by Alkaline Activation of Ferro-Aluminous Fly Ash," Fuel, Vol. 74, No. 8, pp. 1226-1231

(15) Taylor, H. F. W. (1990) Cement Chemistry, Academic Press, pp. 231-237

(16) Tomita, K., Yamane, H., and Kawano, M. (1993) "Synthesis of Smectite from Volcanic Glass at Low Temperature," Clays and Clay Minerals, Vol. 41, No. 6, pp 655-661

(17) Velde, B. (1985) Clay Minerals: A Physico-Chemical Explanation of their Occurrence, Elsevier, Amsterdam 